\title{
Implementasi Metode Breadth First Search Pada Mesin Inferensi Sistem Pakar Gangguan Kejiwaan Tunawisma
}

\author{
Kholid Rohman Saputro (11018187) ${ }^{1}$, Dewi Soyusiawaty(60040497) ${ }^{2}$ \\ Teknik Informatika Universitas Ahmad Dahlan, Jl. Ringroad Selatan, Bantul, Yogyakarta 55191, Indonesia \\ ${ }^{1}$ kholid.top@gmail.com; ${ }^{2}$ dewi.soyusiwaty@tif.uad.ac.id
}

\begin{abstract}
ABSTRAK (10PT)
Gangguan kejiwaan merupakan suatu gangguan psikologis fungsional berupa gangguan mental yang ditandai dengan gejala-gejala psikotik yang khas yang dipengaruhi oleh kemunduran fungsi sosial, sejarah keluarga, penyalahgunaan obat, stres yang berlebihan dan komplikasi kehamilan. Gangguan kejiwaan ini ditandai dengan menonjolnya gejala-gejala positif seperti halusinasi, delusi, dan asosiasi longgar dan gejala-gejala negatif seperti penarikan diri, apati, dan perawatan diri yang buruk. Keterlambatan penangan pada seorang mengalami gangguan kejiwaan akan berdampak buruk, kekambuhan menjadi sering, pengobatan menjadi semakin sulit dan akhirnya akan mengantar penderita pada keadaan kronis berkepanjangan. Tujuan penelitian ini adalah membuat sebuah sistem untuk membantu petugas medis atau perawat dalam mendiagnosa pasien yang mengalami gangguan kejiwaan.

Pengembangan perangkat lunak pada sistem pakar ini meliputi: pengumpulan data dan berbagai sumber yang direpresentasikan dalam basis pengetahuan. Langkah selanjutnya yaitu menganalisa dan melakukan perancangan sistem, pemodelan sistem yang meliputi perancangan diagram konteks, perancangan model data dan konseptual, perancangan tabel dan perancangan aplikasi menggunakan aplikasi sublime text 3 dengan bahasa pemprograman PHP.

Dari penelitian yang dilakukan menghasilkan sebuah perangkat lunak berupa program aplikasi sistem pakar untuk menentukan jenis gangguan kejiwaan yang dapat bekerja sebagai pakar. Untuk keluaran hasil diagnosa berupa informasi: Gejala yang di inputkan, nama gangguan, gejala umum, defenisi gangguan, nilai keakuratan dan pengobatannya. Setelah dilakukan pengujian sistem oleh petugas dan perawat, maka di dapatkan hasil kelayakan untuk kategori sangat setuju $=39 \%$, sedangkan setuju $=61 \%$.
\end{abstract}

Ciptaan disebarluaskan di bawah lisensi CC-BY-SA.

Kata kunci: Gangguan Kejiwaan, Sistem Pakar, Breadth First Search

\section{Pendahuluan}

Dinas sosial yang mempunyai tugas dalam melaksanakan urusan Pemerintah Daerah di bidang sosial, dan kewenangan dekonsentrasi serta tugas pembuatan yang diberikan oleh Perintah. UPT PANTI KARYA (Unit Pelaksanaan Teknis Panti Karya) yang berlokasi di Kecamatan Mergangsan Kelurahan Brontokusuman Karanganyar Yogyakarta, merupakan dinas sosial yang bergerak pada panti penampungan orang-orang tunawisma. UPT PANTI KARYA yang mempunyai luas $6.842 \mathrm{M}^{2}$, saat ini menampung kuranglebih 100 orang tunawisma. Namun jumlah ini bisa berubahrubah setiap bulannya, tergantung kepada pasien yang datang untuk penyembuhan dan pasien yang keluar karna dinyatakan sudah sembuh oleh dokter. Dimana dari kuranglebih 100 orang tunawisma tersebut terdiri dari berbagai macam usia kalangan. Mulai dari anak-anak, remaja, dewasa dan orang tua. Dari jenis-jenis gangguan kejiwaan dikelompokkan menjadi 8 golongan, dan dari segi gejala terdapat 68 nama-nama gejala berdasarkan permasalahan yang terjadi pada gangguan 
kejiwaan di UPT Panti Karya. Sehingga membuat petugas medis yang berjumlah 2 orang kesulitan dalam mengelempokkannya gangguan untuk menanggulangi setiap pasien di panti karya tersebut.

Setiap 5 bulan sekali biasanya pihak medis melakukan pengecekan kejiwaan berkala pada setiap pasien yang berada di Panti Karya. Sehingga diperlukannya penanganan yang tepat dalam memberikan sebuah solusi untuk mengidentifikasi gangguan kejiwaan dari setiap golongan gangguan. Pada lokasi tempat penampungan orang-orang tunawisma di PANTI KARYA sendiri membagi tempat penampungan menjadi dua bagian. Dimana pada bagian A yang letaknya disebelah selatan digunakan untuk orang-orang tunawisma yang masih bisa diajak dalam berkomunikasi, sedangkan pada bagian tempat B yang letaknya disebelah utara dikhususkan untuk penampungan orang-orang tunawisma yang memang pada kasusnya memiliki latar belakang mental yang sangat susah untuk bisa diajak dalam berkomunikasi. Untuk membantu dalam mengidentifikasi dan penanganannya, maka dibutuhkan sebuah sistem yang bisa membantu dalam memberikan informasi dari setiap permasalahan yang ada. Sehingga dalam permasalahan orangorang tunawisma ini diperlukan sebuah kajian-kajian yang sudah ada sebelumnya, agar bisa dilakukan pengembangan dari teori-teori yang sudah ada. Untuk dapat memberikan solusi dari permasalahan pada orang-orang tunawisma ini, diperlukan informasi yang lebih detail dari setiap penanganan masing-masih dari setiap studi kasusnya.

Untuk melakukan penelusuran pencarian data, terdapat tiga buah metode penelusuran, yaitu: Metode Breadth First Search, Depth Fristh Search, dan Best First Search. Pada studi kasus gangguan kejiwaan tunawisma ini metode penelusuran yang akan digunakan menggunakan metode penelusuran Breadth First Search. Karena metode Breadth First Search ini memiliki kelebihan tidak akan menemukan jalan buntu dalam proses pencarian karena jika terdapat satu solusi maka solusi minimum akan ditemukan.

Tujuan implementasi BFS pada studi kasus ini adalah untuk membantu dokter dalam proses identifikasi gejala-gejala pada masing-masing golongan gangguan kejiwaan.

\section{Kajian Pustaka}

Penelitian yang dilakukan mengacu pada penelitian terdahulu yang dilakukan oleh: Munawir (2011) Sistem pakar konsultasi siswa bermasalah, Perwira (2013) Sistem pakar untuk mendiagnosa penyakit TBC paru dengan menggunakan metode penelusuran Breadth First Search, Pratama (2015) Sistem pakar diagnosa penyakit ginjal dan saluran kemih dengan metode Breadth First Search, Yuliansyah (2013) Sistem pakar berbasis web diagnosa jenis penyakit pada lambung manusia.

Berdasarkan penelitian diatas, maka penelitian ini dilakukan untuk pedoman melakukan langkah-langkah penerepan dalam penelusuran pencarian dengan metode Breadth Frist Search untuk gangguan kejiwaan pada tunawisma di UPT Panti Karya.

\subsection{Kecerdasan Buatan (Artificial Intelligent)}

Artificial Intelligence (AI) atau kecerdasan buatan adalah suatu ilmu pengetahuan atau teknologi yang berdasarkan pada disiplin ilmu seperti ilmu komputer, biologi, psikologi, ilmu bahasa, matematika dan teknik (Rusdi, 2003).

Menurut Durkin bahwa secara umum, sistempakar adalah suatu program komputer yang dirancang untuk memodelkan kemampuan penyelesaian masalah yang dilakukan seorang pakar.

\subsection{Metode Pencarian}

Breadth First Search

Pada gambar 1 dengan menggunakan metode Breadth-First Search ini adalah semua node pada level $\mathrm{n}$ akan dikunjungi terlebih dahulu sebelum mengunjungi pada node-node pada level $\mathrm{n}+1$. Pencarian dimulai pada pencarian node akar terus ke lvl 1 dari kiri ke kanan, kemudian berpindah ke level berikutnya dari kiri ke kanan hingga solusi ditemukan. 


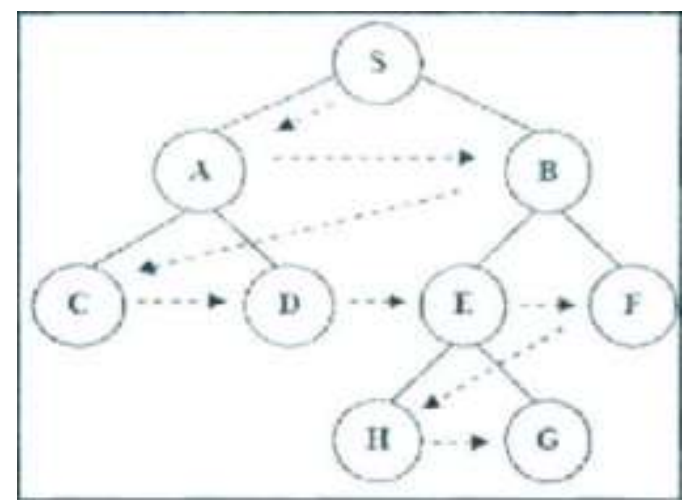

Gambar 1 Metode Breadth First Search

Keuntungan:

1. Tidak akan menemukan jalan buntu

2. Jika ada 1 solussi, maka Breadth-First Search akan menemukannya dan jika ada lebih dari 1 solusi, maka solusi minimum akan ditemukan.

Kelemahan:

1. Membutuhkan memory yang cukup banyak

2. Membutuhkan waktu yang cukup lama, karena akan menguji $n$ level untuk mendapatkan solusi pada level yang ke-(n+1).

\section{Metode Penelitian}

Subyek penelitian pada tugas akhir ini adalah metode beardth first search untuk mengidentifikasi gangguan kejiwaan dan penangulangannya pada tunawisma yang diimplementasikan dalam bahasa pemrograman PHP. Desain sistem yang dibuat ini bertujuan untuk dapat membantu tenaga medis dalam memberikan alternatif tindakan/penanganan terbaik dalam setiap permasalahan yang terjadi di Panti Karya Sosial Yogyakarta.

\subsection{Subyek Penelitian}

Subyek penelitian pada studi kasus ini adalah implementasi metode Breadth First Search pada mesin inferensi sistem pakar gangguan kejiwaan. Dimana program yang digunakan untuk pembuatan aplikasi ini menggunakan aplikasi sublime text 3, dengan bahasa pemprograman PHP, dan menggunakan database PHP MyAdmin \& Navicat.

\subsection{Metode Pengumpulan Data}

Metode pengumpulan data merupakan cara untuk memperoleh data dalam penelitian. Tujuan dari metode pengumpulan data adalah untuk dapat menetukan cara pengumpulan data yang akan digunakan untuk penelitian. Adapun metode yang digunakan dalam penelitian antara lain.

a. Studi Pustaka

Merupakan metode yang dilakukan dengan mencari, membaca dan mengumpulkan buku literatur atau buku-buku referensi yang berhubungan dengan penelitian yang di lakukan.

b. Wawancara

Merupakan metode dengan melakukan wawancara langsung kepada Dokter dr.Siti Nurhidayati,SpKJ di Panti Karya, yang menjadi pakar dalam pembuatan aplikasi ini. Dalam hal ini pakar penanganan orang-orang gelandangan adalah dokter medis panti karya, yang bernar-benar sesuai dengan fakta yang ada. Data yang diambil berupa permasalahan, gejala dan penanganan.

c. Observasi

Merupakan metode pengamatan secara langsung terhadap cara kerja pakar tau docter dalam mendiagnosa pasien. Selain melakukan pengamatan juga melakukan pencatatan dokumen yang berkaitan dengan subjek penelitian secara cermat dan sistematis.

\subsection{Desain}

a. Perancangan diagram konteks 
Berfungsi untuk memudahkan pemodelan dan fungsi di dalam pengembangan sistem.

b. Pembuatan diagram alir

Berfungsi untuk memahami sistem secara logika, yang bertujuan untuk dapat menggambarkan jalannya suatu sistem yang akan di kembangkan.

c. Desain basis data (Database)

Berfungsi untuk menampung basis pengetahuan dan basis aturan.

d. Desain antar muka

Digunakan sebagai jembatan antara user dan sistem, sehingga dibuat interface yang dapat di pahami oleh pengguna dan sesuai dengan program aplikasi yang dibuat, sehingga aplikasi berjalan dengan baik.

\subsection{Implementasi}

Pada tahapan implementasi sistem ini ada dua tahapan yaitu tahapan pengkoden dan hasil penelitian. Tahapan pengkoden yaitu desain sistem yang telah dirancang akan diubah ke dalam bahsa yang akan dimengerti komputer.

\subsection{Pengujian Sistem}

Untuk tahapan pengujian sistem dilakukan dua buah pengujian sistem yaitu, pengujian dengan menggunakan Black box test dan pengujian menggunakan alpha test.

\section{Hasil Dan Pembahasan}

\subsection{Analisis}

Analisis kebutuhan sistem merupakan suatu tahapan dalam membangun sistem pakar. Di dalam analsis kebutuhan sistem, data yang berhubungan dengan informasi gangguan kejiwaan. Data yang telah terkumpul akan di identifikasi sesuai dengan gejala-gejala yang dialamai oleh pasien sehingga didapatkan hasil berupa nama gangguan kejiwaan yang sesuai dengan nama gejala-gejala yang telah di inputkan. Analisis kebutuhan dengan spesifikasi perangkat lunak yang dibutuhkan meliputi:

- Pakar yaitu seseorang yang ahli dalam bidang psikologis mental dan gejala-gejala gangguan kejiwaan. Dalam hal ini sistem berperan sebagai asisten.

- Petugas medis yaitu orang yang akan menjalankan sistem untuk melakukan konsultasi kepada pasien.

\subsection{Basis Pengetahuan}

a. Daftar tabel gejala

\begin{tabular}{|l|l|c|}
\hline Kd_Gejala & Nama_Gejala & Probabilitas \\
\hline GL042 & Memiliki keyakinan yang aneh & 0,6 \\
\hline GL043 & Tingkahlaku eksentrik (tidak wajar) & 0,4 \\
\hline GL044 & Adanya kemunduran diri & 0,7 \\
\hline
\end{tabular}

b. Daftar tabel gangguan

\begin{tabular}{|c|l|}
\hline Kode Gangguan & \multicolumn{1}{|c|}{ Nama Gangguan } \\
\hline GG001 & Gangguan Kejiwaan Paranoid \\
\hline GG002 & Gangguan Kejiwaan Hebefronik \\
\hline GG003 & Gangguan Kejiwaan Katatonik \\
\hline
\end{tabular}

c. Daftar tabel pembentukan aturan gejala gangguan

\begin{tabular}{|c|c|l|}
\hline Kd_gangguan & Aturan & \multicolumn{1}{c|}{ Gejala } \\
\hline GG001 & A5 & $\begin{array}{l}\text { If Adanya kemunduran diri (GL044) And waham } \\
\text { tidak tersistemaik (GL054) And memperlihatkan } \\
\text { tingkah laku yang aneh (GL049) And sikap pasif dan } \\
\text { ketiadaan inisiatif (GL048) Then ganggung kejiwaan } \\
\text { katatonik (GG003) ). Mrule=0,50 }\end{array}$ \\
\hline & A6 & If Tidak mau bergaul dan kontak dengan orang lain \\
\hline
\end{tabular}




\begin{tabular}{|l|l|l|}
\hline & $\begin{array}{l}\text { (GL046) And perawatan diri yang buruk (GL045) } \\
\text { And penarikan diri dari hubungan sosial (G039) } \\
\text { Then ganggung kejiwaan katatonik (GG003) }) . \\
\text { Mrule=0,70 }\end{array}$ \\
\hline
\end{tabular}

\subsection{Deskripsi Sistem}

a. Pemodelan Proses

Pemodelan proses disajikan dalam Gambar 2 bentu Data Flow Diagram (DFD). Data Flow Diagram (DFD) dimulai dari bentuk yang paling umum yaitu diagram konteks, kemudia dari diagram konteks ini diturunkan menjadi betuk yang lebih detail. Data Flow Diagram dapat dilihat pada gambar berikut ini.

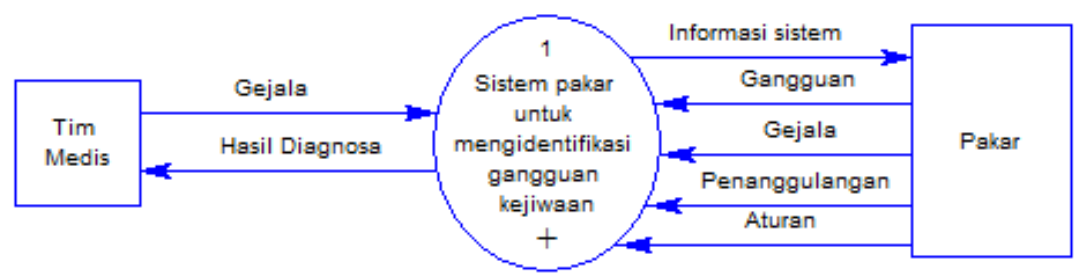

Gambar 2 Data Flow Diagram (DFD)

b. Pemodelan Data

Pemodelan data disajikan pada gambar 3 dengan Entity Relationship Diagram (ERD). Entity Relationship Diagram (ERD) adalah sarana untuk menggambarkan hubungan antara data dalam sebuah sistem, ERD menggunakan sebuah notasi dan simbol untuk menggambarkan struktur dan hubungan antar data. Entity Relationship Diagram (ERD) Sistem pakar untuk gangguan kejiwaan ini dapat dilihat pada pada gambar berikut ini.

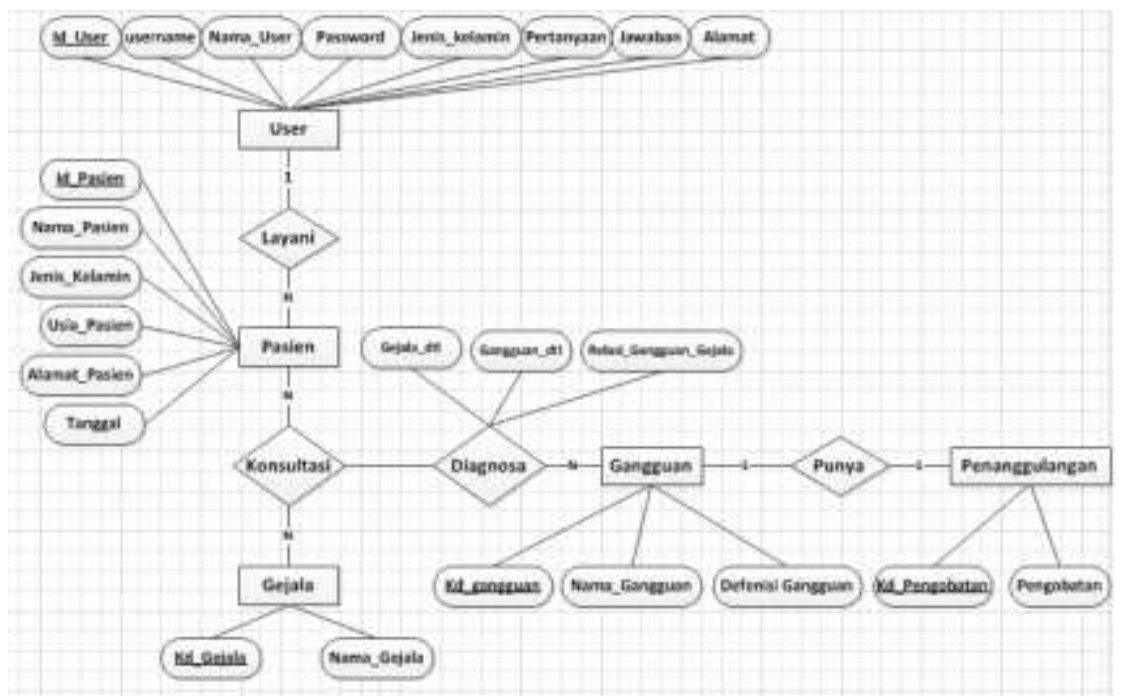

Gambar 3 Entity Relationship Diagram (ERD)

Pada tahapan awal user yang merupakan petugas medis atau perawat melayani pasien, pasien melakukan konsultasi berupa gejala-gejala pada petugas medis. Pada data-data gejala pasien yang di inputkan pada aplikasi program, dilakukan penelusuran diagnosa untuk dapat menampilkan hasil berupa data gangguan. Pada data gangguan terdapat penanggulangan untuk setiap masingmasih gejala yang dialami oleh pasien.

\subsection{Implementasi dan Pengujian}

a. Implementasi 
Menu utama sistem pakar dapat dilihat pada Gambar 4. Pada gambar menu utama terdapat menu untuk Login, Beranda, petunjuk dan informasi.

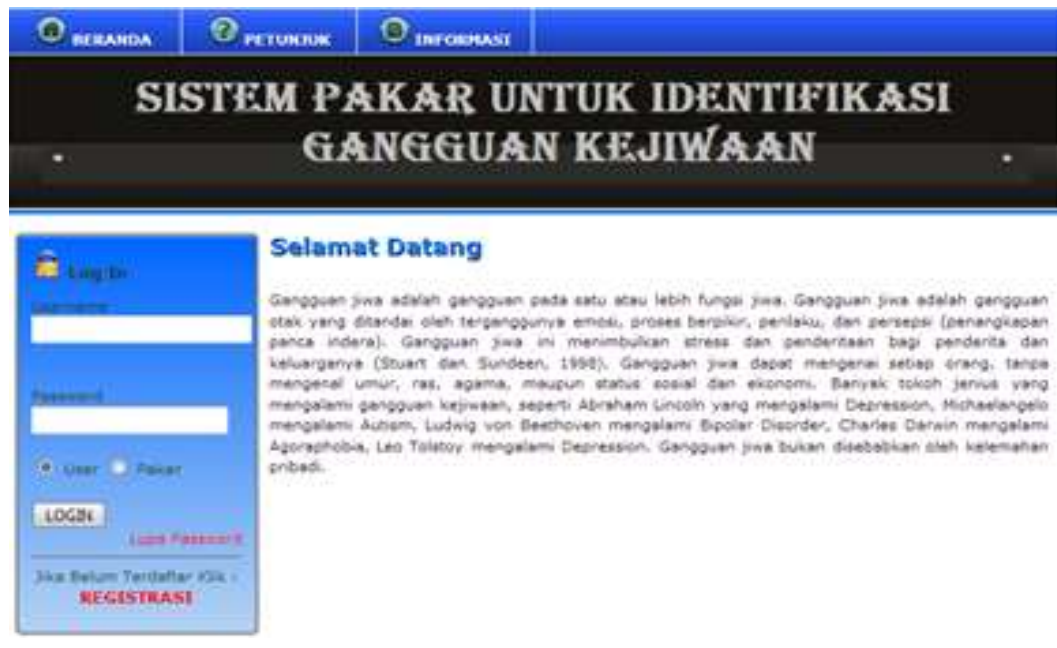

Gambar 4 Menu utama

Halaman input data gejala pada Gambar 5 berisi tentang masukkan inputan data-data gejala yang akan di proses nantinya untuk mendapatkan hasil gangguan diagnosa.

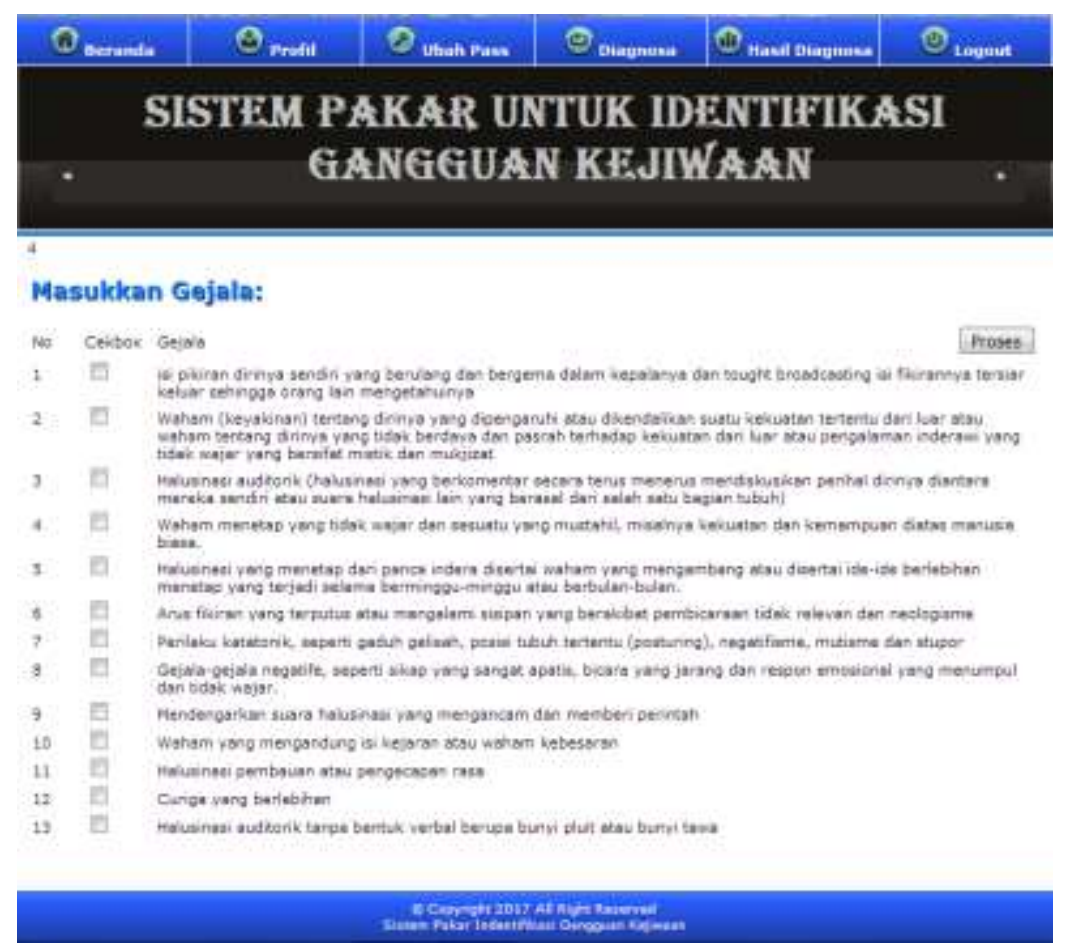

Gambar 5 Masukan gejala

Halaman hasil diagnosa pada Gambar 6 berisi data-data seperti Biodata Pasien dimana terdiri dari: nama, usia, jenis kelamin dan alamat. Hasil diagnosa, terdiri dari: nama gangguan, gejala umum, nilai keakuratan dan pengobatan. 


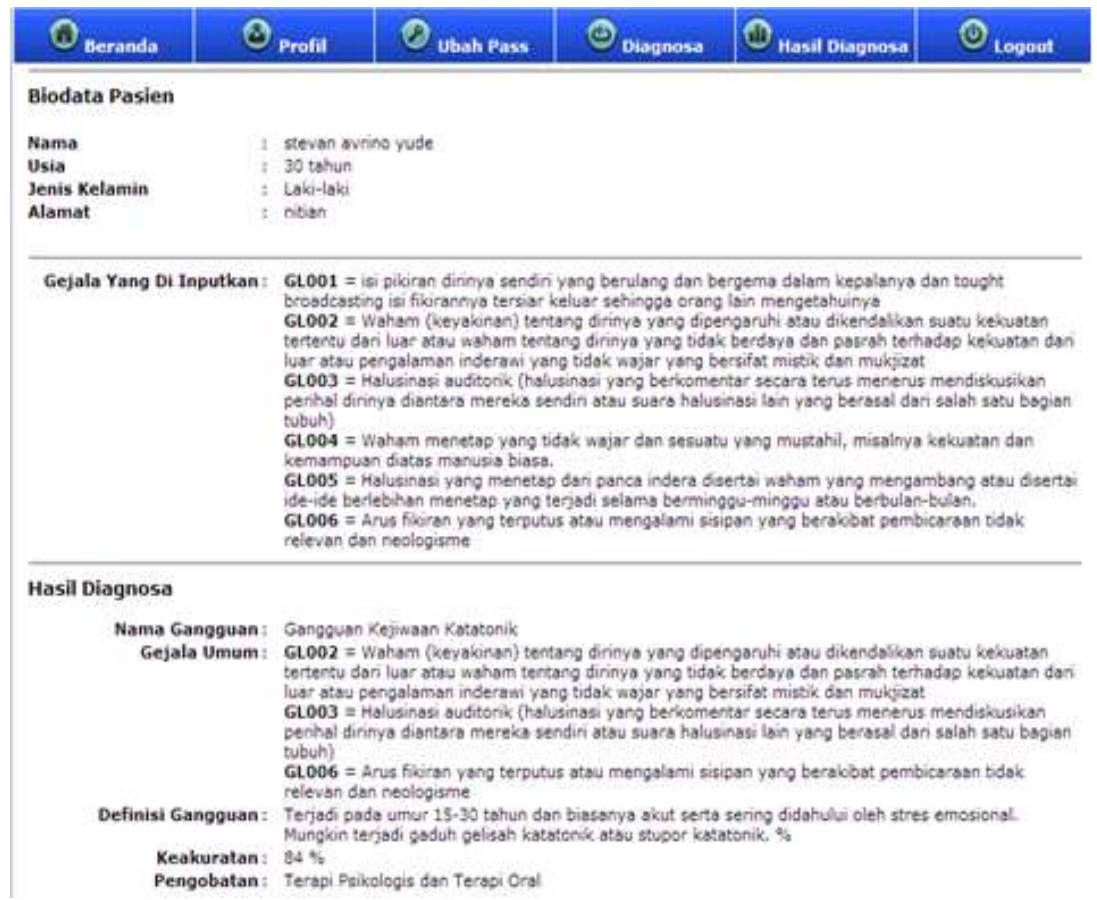

Gambar 6 Hasil Diagnosa

b. Pengujian

Sistem ini menggunakan dua jenis pengujian yaitu:

- Black Box Test

Pengujian ini melibatkan seorang pakar gangguan kejiwaan yaitu dr.Siti Nurhidayati SpKJ, pengujian ditekankan pada pemasukan data, penentuan aturan diagnosa gangguan dan informasi yang dihasilkan.

Berdasarkan hasil diatas didapat persentase penilaian terhdapat sistem aplikasi yaitu, Y:14/14x $100 \%, T=0 / 14 x 100 \%=0$. Dari hasil uji persentase tersebut dapat ditarik kesimpulan bahwa data dan informasi yang disampaikan sudah sesuai dengan ilmu pengetahuan di bidang kesehatan, khususnya dalam mengalisa dan mendiagnosa gangguan kejiwaan.

\section{- Alpha Test}

Untuk pengejian sistem menggunakan Alpha test dilakukan oleh 7 Orang. Berdasarkan hasil diatas, dapat diperoleh persentase penilaian terhdapat sistem yaitu: jawaban $\mathrm{SS}=$ $19 / 49 \times 100 \%=39 \%$, jawaban $\mathrm{S}=30 / 49 \times 100 \%=61 \%$, jawaban $\mathrm{KS}=0 / 49 \times 100 \%=0 \%$, jawaban $\mathrm{TS}=0 / 49 \times 100 \%=0 \%$. Dari hasil penilaian terhadap sistem, maka dapat disimpulkan bahwa sistem layak dipergunakan untuk mendiagnosa gangguan kejiwaan.

\section{Kesimpulan}

Berdasarkan hasil pengembangan dan pembahasan maka dapat ditarik kesimpulan:

1. Dari penelitian dihasilkan sebuah perangkat lunak (sofware) baru tentang metode Breadth Frist Search untuk mendiagnosa gangguan kejiwaan. Aplikasi kejiwaan ini saling berelasi antara gejala, gangguan, dan nilai kepastian. Sistem ini dapat digunakan sebagai acuan media konsultasi petugas medis untuk melakukan kelayakan olah data antara gejala dengan gangguan.

2. Perangkat lunak yang dihasilkan mampu melakukan penelusuran gangguan kejiwaan berdasarkan gejala yang dimasukkan dan dapat memberikan data gangguan, penanggulangan, defenisi dan nilai keakuratannya berdasarkan pada hasil pelacakan pada tabel relasi antara gejala dengan gangguan.

3. Berdasarkan hasil dari pengujian sistem dengan menggunakan pengujian Black box test didapatkan hasil dari pakar bahwa sistem berjalan dengan baik bisa untuk melakukan input, hapus, edit dengan benar. Sedangkan pengujian Alpha test yang melibatkan petugas dan perawat yang berjumlah 7 orang, didapatkan hasil bahwa yang menyatakan sangat setuju=39\%, 
setuju $=61 \%$, kurang setuju $=0 \%$ tidak setuju $=0 \%$, total $100 \%$. Maka didapatkan hasil bahwa sistem layak untuk digunakan sebagai penelusuran gangguan kejiwaan pada tunawisma.

\section{Daftar Pustaka}

Munawir Arip, Sistem pakar konsultasi siswa bermasalah, Bandung 2011

Gunawan, Indra, Aplikasi Sistem Pakar Diagnosa Gangguan Kejiwaan, Pangkal Pinang 2011

Abdul Kadir \& Terra Ch.l Twiwahyuni, Pengenalan Teknologi Informasi, Ani Yogyakarta,2005

Desiana,Anita dan Muhammad Arhani, 2007, Konsep Kecerdasan Buatan, Yogyakarta, Andhi Offiset

Kusrini, 2006, Sistem Pakar Teori dan Aplikasi, Yogyakarta, Andhi Offiset

Fathansyah, 2004, Basis Data, Informatika, Bandung.

Kaplain, dan Sadock, 1997, Ilmu Pengetahuan Perilaku Psikiatri Klinis Jilid I, Binarupa Aksara, Jakarta

Kusumadewi, Sri, 2003, Artifactial Intelegence (Teknik dan Aplikasinya), Graha Ilmu, Yogyakarta

Muslim, Rusdi,dr, 2001, Penggunaan Klinis Obat Psikoterapik, Jakarta

Muhammad, Arhani, 2005, Konsep Dasar Sistem Pakar, Andi, Yogyakarta

Nugroho, Adi, 2004, Konsep Pengembangan Sistem Basis Data, Informatika Bandung, Bandung

Rochmawati, Dewi, 2003, Aplikasi Psikodiagnotik Menggunakan Sistem Pakar, Skripsi-S1, Universitas Ahmad Dahlan, Yogyakarta 